\title{
LONG-TERM HURRICANE EFFECTS ON POPULATIONS OF TWO EPIPHYTIC ORCHID SPECIES FROM GUANAHACABIBES PENINSULA, CUBA
}

\author{
Ernesto Múuica ${ }^{1,4}$ Josep Raventós², Elaine GonZÁlez ${ }^{3}$ \& Andreu BoneT ${ }^{2}$
}

${ }^{1}$ Center for Research and Environment Services ECOVIDA, Km. 2,5 Carretera Luis Lazo, Pinar del Río, 22700, Cuba

${ }^{2}$ Department of Ecology, Faculty of Biology, University of Alicante, Sant Vincent del Raspeig s/n, Alicante, Spain ${ }^{3}$ Soroa Orchid Garden, University of Pinar del Río, km 8 Carretera Soroa, Candelaria, Artemisa, Cuba

${ }^{4}$ Author for correspondence: emujica@ecovida.vega.inf.cu

AвSTRACT. Disturbances affect the spatial and temporal dynamics of ecosystems. The lack of long-term demographic data affects our understanding the effects of high intensity disturbances such as hurricanes. In this paper we assess population recovery of two epiphytic orchids, Broughtonia cubensis (Lindl.) Cogn. and Dendrophylax lindenii (Lindl.) Bentham ex Rolfe, for 7-8 years after Hurricane Ivan (September 2004, category 5, Saffir-Simpson scale). To analyze some spatial components, we applied recent techniques of marked point pattern analysis to ask two questions: 1) at level of phorophytes, was the height and basal diameter (DBH) related to the damage caused by hurricane Ivan, and 2) was the height of epiphytic orchids on phorophytes related to the damage, too? We found that phorophyte damage caused by the hurricane depends on the ecosystem in which the trees were found. Furthermore, damage to individuals of $B$. cubensis was independent of their height above ground, in contrast to those of $D$. lindenii. To assess orchid recovery we compared pre- and post-hurricane measures of vegetative traits: number of leaves and leaf area for $B$. cubensis and number of living roots and mean root length for the leafless $D$. lindenii. We also compared changes in the production of inflorescences, flowers, and fruits over this recovery period. We found that vegetative parts of $B$. cubensis recovered, whereas those of $D$. lindenii did not. However, neither reproductive effort nor success returned to pre-hurricane levels for either species. The greatest decline in fruit set was by $D$. lindenii, which may reflect a significant decline in availability of their sphingid pollinators. The relative population growth rate from 2004 to 2012 for B. cubensis indicates that the population has stabilized. Unfortunately, analysis of our eight-year data set (2003-2011) for $D$. lindenii shows negative population growth. Despite an evolutionary history exposed to severe periodic storms not all orchid species are resilient. .

KEY WORDS: mepiphytes, hurricane recovery, Orchidaceae, Caribbean

Orchidaceae is one of the largest flowering plant families and is primarily threatened by human activity and habitat changes (Kindlman et al. 2002). With global warming, the frequency and severity of storms including Caribbean hurricanes is expected to rise, which can cause widespread habitat destruction.

The role of disturbance in affecting the spatial and temporal dynamics of ecosystems is increasingly recognized as a dominant theme in ecology. Understanding the effects of infrequent and highintensity disturbances such as hurricanes is difficult, especially in tropical environments where there is a lack of long-term demographic data (Willig et al. 2011). The Caribbean Basin is characterized by high cyclonic activity (Walker et al. 1991; Landsea et al. 1999), with over 2000 hurricanes recorded from 1851 to 2008. Consequently, the Caribbean Basin is an environment in which disturbance regimes likely produce a sequence of events in which cumulative or interactive effects play a dominant role in determining the abundance and distribution of organisms (Waide and Lugo 1992; Willig et al. 2011).

Caribbean hurricanes have affected ecosystems (Lodge \& McDowell 1991), plant population dynamics (Lugo et al. 1983), food webs (Spiller and Schoener 2007), and nutrient cycling (Sanford et al. 1991). Especially threatening are the effects of hurricanes on epiphytic orchid communities due to 
phorophyte damage, which could result in the loss of large components of the community (RodríguezRobles et al. 1990; You \& Petty 1991; Migenis and Ackerman 1993; Tremblay 2008). This exacerbates an already sensitive situation in which many species are threatened and endangered (Salazar 1996; Morales 2000) primarily because of collectors and anthropogenic habitat changes (Kindlman et al. 2002). Most studies indicate that future changes in hurricane frequencies in response to global warming will be region-dependent (Pielke et al. 2005). Thus, it is all the more important to understand the long-term effects of successive disturbances on the resilience of biological systems (Schoener \& Spiller 2006).

Our general goal was to determine recovery patterns in tropical epiphytic orchids after a severe weather event. Specifically:

- Is the height and DBH of phorophytes relevant to the severity of tree damage?

- Is the positional height of orchids on phorophytes related to the degree of damage caused by Hurricane Ivan?

- Do species recover over a period of 7-8 years?

- Are patterns of recovery similar for orchid species subjected to the same disturbance?

\section{Materials and methods}

Study area - The Biosphere Reserve "Peninsula de Guanahacabibes" is located in the westernmost region of Cuba in the municipality of Sandino, Pinar del Río province. The peninsula is long and narrow, with flat areas covering approximately 101,500 hectares (Herrera et al. 1987) of which 28,000 belong to the Guanahacabibes National Park. Our research took place at Cabo San Antonio.

The species - Broughtonia cubensis is endemic to Cuba and has a high ornamental value. It is epiphytic, occurring in xerophytic vegetation of Guanahacabibes and in low mountain ranges of La Coca, Mayabeque province. It blooms between January and March, with a peak in February (Mújica et al. 2000). Dendrophylax lindenii is a large-flowered, ornamental epiphytic species native to Cuba and Florida (U.S.A.). Its leaves are bract-like and ephemeral, giving it a leafless appearance. Virtually all photosynthesis is by its extensive root system, presumably making it vulnerable to habitat changes. In Guanahacabibes, $D$. lindenii inhabits semideciduous forests and elevations near sea level. It blooms mainly from October to December (Mújica et al. 2000).

Data collection and analysis - The xeromorphic coastal vegetation occupied by $B$. cubensis was intensively studied from March 2004 to March 2012 using 10 arbitrarily located transects $(5-7 \times 100 \mathrm{~m})$. Where orchids were most common, we established five $20 \times 20 \mathrm{~m}$ plots. For $D$. lindenii, we established two $10-15 \times 1000 \mathrm{~m}$ transects in the semideciduous forest. On the sites with high occurrence of orchids we created three $20 \times 20 \mathrm{~m}$ plots. All occupied trees were identified and mapped, and all orchid plants were individually marked.

For analysis of damage on phorophytes and number of individuals in each population, we used the information in the mapped plots. For analysis of vegetative and reproductive variables and relative population growth rates (RGR), we used transect data.

To determine the effect of Hurricane Ivan on orchid phorophytes, we assessed effects at two different levels: damage to phorophytes (orchid host-trees) and damage to the orchids. For phorophyte species, we established two patterns of damage: severely affected phorophytes (tip-ups or snap-offs) and phorophytes less affected (defoliation and branch breakage). We tested whether tree height or DBH influenced whether or not phorophytes were severely damaged.

Our orchid data included the number of individuals on each phorophyte and their height on the tree above ground. For B. cubensis we collected information on number of leaves and leaf area, and for $D$. lindenii we calculated the number of living roots and mean length of all living roots. Reproductive data for both species included the percentage of plants that failed to produce flowers, number and length of inflorescences, number of flowers produced per inflorescence, and the number of flowers and fruits. We compared traits before Hurricane Ivan, immediately afterwards (2004), and then eight years later.

Finally, we evaluated the resilience of the two orchid species after the hurricane by changes in the relative growth rate (RGR) and using transition matrix analyses after the impact on their populations (from 2006 to 2011 for D. lindenii and 2006-2012 for B. cubensis). Matrix analyses are the most powerful methods for predictive 
analysis of population dynamics. For plants, stage-based matrix projection models (Lefkovitch 1965) are more appropriate for analyzing plant population dynamics than age-based models (Caswell 2001 and references therein) because life-history stage (for example, seed, seedling, juvenile, adult, senescent) and size are more important than age in determining demographic parameters (Harper 1977). For the matrix analysis we structured the populations in four life stages on the basis of leaf area for B. cubensis and mean root length in $D$. lindenii. In plants it is common to use size as a variable to define life stages in a population. Other studies carried out in Central America use length of the most recently produced pseudobulb (Zotz \& Schmidt 2006). However, in our study we decided to use leaf area of each individual to define the life stages in the population of $B$. cubensis following Mújica (2007). Annually we measured length and width of leaves of each individual to obtain their leaf area. In the case of the leafless $D$. lindenii, the only alternative was to calculate the mean length of all living roots on the individual plant.

Statistics - For the comparative analyses between the possible relationship of the height and DBH with the damage caused to the phorophytes, we used the MannWhitney U-test. The same statistical analysis was used to evaluate the possible relationship of the height where the individuals of the species are located with the degree of damage.

The annual comparisons of means of the vegetative and reproductive variables were analyzed by oneway ANOVA. To establish similarities or differences between groups, we used the Student-Newman-Keuls.

\section{Results}

Orchids and the phorophyte community - In the five $20 \times 20 \mathrm{~m}$ plots, B. cubensis occupied 205 trees and 17 different phorophyte species. The most common host trees were Plumeria tuberculata Lodd. (37.1\%) and Erythroxylum areolatum L. (10.2\%). In the three $20 \times$ $20 \mathrm{~m} \mathrm{D}$. lindenii plots, we found plants on 92 trees representing 13 different species. The most common phorophytes were Comocladia dentata Jacq. (16\%), Maba crasinervis Urb. (13\%), and Cedrela odorata L. (9\%).

Damage caused by Hurricane Ivan: height and DBH of phorophytes - The severity of hurricane damage to $B$. cubensis phorophytes was independent of phorophyte height (Mann-Whitney U-test 409.9: $p=0.336 ; n=121$ ) and DBH (Mann-Whitney U-test 415.5: $p=0.402$; $n=121$ ). Damage to phorophytes of $D$. lindenii was significantly dependent on tree height (Mann-Whitney U-test 29.0: $p<0.04 ; n=22$ ), yet severity of damage was independent of DBH (Mann-Whitney U-test 415.5: $p=0.228 ; n=22$ ).

Impact of Hurricane Ivan on populations of $\mathrm{B}$. cubensis and D. lindenii - Prior to Hurricane Ivan the population of B. cubensis had 377 individuals in the five plots. The storm reduced the number of individuals by $29.2 \%$. In the following years, the population began to recover but had not yet reached the numbers before the storm. In 2011 and 2012 the population suffered predation by people in plot 3, which negatively affected the trajectory of population growth (Table 1).

TABLE 1. Census totals of B. cubensis in $20 \times 20 \mathrm{~m}$ plots. The 2004 census was made prior to the hurricane.

\begin{tabular}{|c|c|c|c|c|c|c|c|c|c|}
\hline Plots & 2004 & 2005 & 2006 & 2007 & 2008 & 2009 & 2010 & 2011 & 2012 \\
\hline 1 & 120 & 77 & 88 & 85 & 84 & 81 & 84 & 73 & 66 \\
\hline 2 & 51 & 36 & 46 & 43 & 41 & 42 & 42 & 45 & 46 \\
\hline 3 & 72 & 50 & 52 & 55 & 54 & 55 & 45 & 27 & 18 \\
\hline 4 & 46 & 43 & 52 & 50 & 48 & 50 & 49 & 42 & 41 \\
\hline 5 & 88 & 77 & 86 & 89 & 93 & 95 & 100 & 137 & 132 \\
\hline Total & 377 & 283 & 324 & 322 & 320 & 323 & 320 & 324 & 303 \\
\hline
\end{tabular}


TABle 2. Census totals of $D$. lindenii in $20 \times 20 \mathrm{~m}$ plots. Pre-hurricane data are from 2003 .

\begin{tabular}{|c|c|c|c|c|c|c|c|c|c|}
\hline Plots & 2003 & 2004 & 2005 & 2006 & 2007 & 2008 & 2009 & 2010 & 2011 \\
\hline 1 & 63 & 30 & 28 & 27 & 24 & 24 & 22 & 19 & 17 \\
\hline 2 & 45 & 26 & 23 & 20 & 19 & 17 & 13 & 14 & 14 \\
\hline 3 & 45 & 8 & 7 & 6 & 5 & 2 & 0 & 0 & 0 \\
\hline Total & 153 & 64 & 58 & 53 & 48 & 43 & 35 & 33 & 31 \\
\hline
\end{tabular}

The population of $D$. lindenii had been much smaller than that of B. cubensis. Before the hurricane (2003), we censused 153 individuals in the three plots. Hurricane Ivan immediately reduced the size of the population by $60 \%$, and it has continued to decrease since then (Table 2).

The positional height of $B$. cubensis on their phorophytes had no differential effect on plant damage (Fig. 1), but there is a strong relationship between height above ground and damage to D. lindenii (Fig. 2).

Hurricane impacts on vegetative traits of $\mathrm{B}$. cubensis and D. lindenii - For this analysis, we used 2006-2012 data from both plots and transects. Prior to the hurricane

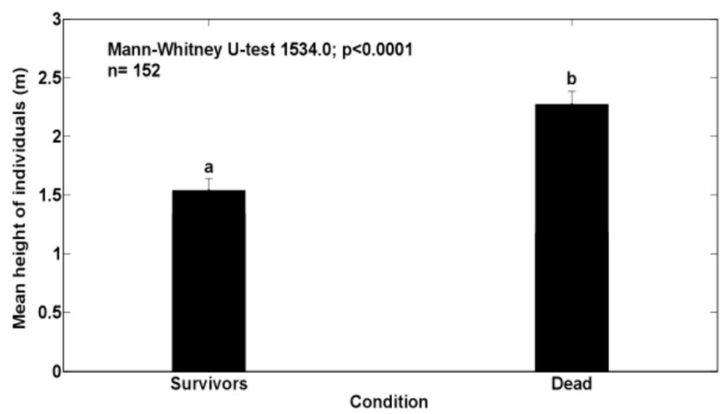

FIGURE 1. Relationship between height on tree and degree of damage to $B$. cubensis.

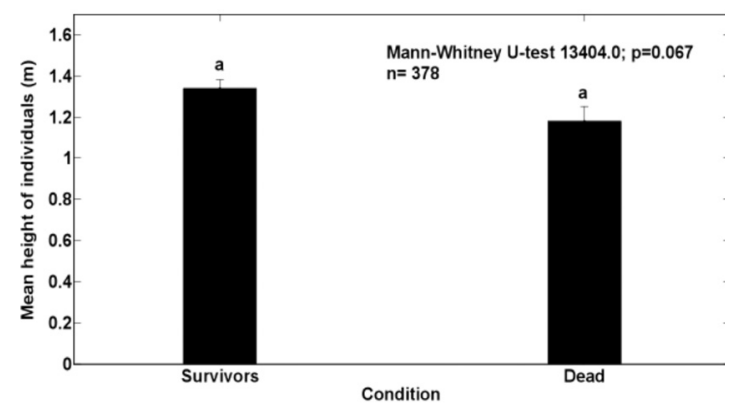

FIGURE 2. Relationship between height on tree and degree of damage to $D$. lindenii. in 2004, B. cubensis averaged 4.8 leaves per plant. Afterwards, the mean dropped to 2.6, and by 2012 the plants had not yet recovered to pre-hurricane levels (F: 5.982; $\mathrm{p}<0.0001)$. While leaf number did not recover, leaf area did to the extent that in 2012 values exceeded previous ones. The values for 2005, 2006, and 2007 were significantly different (F: $3.273 ; \mathrm{p}<0.001$ ) (Table 3). Dendrophylax lindenii showed the same behavior as B. cubensis (Table 4). Hurricane Ivan caused a loss in number of living roots. With a mean of 8.67 roots per plant, it fell to 3.62. In the following years the species did not recover with highly significant differences (F: 24.438; $<$ 0.0001). In the case of the mean length of the living roots, the same thing happened as in B. cubensis. The values for 2004 and 2005 were significantly different each year (F: 12.778; $\mathrm{p}<0.0001$ ).

Hurricane impacts on reproductive effort and success for B. cubensis and D. lindenii - Before Hurricane Ivan, $94.7 \%$ of adult plants of $B$. cubensis produced flowers. The hurricane drastically reduced reproductive

TABLE 3. Recovery based on number of leaves and leaf area in B. cubensis. The 2004 data are pre-hurricane. Trait values followed by different letters are significantly different from one another.

\begin{tabular}{|c|c|c|c|}
\hline Years & Number of leaves & Leaf area $\left(\mathbf{c m}^{2}\right)$ & $\boldsymbol{n}$ \\
\hline 2004 & $4.83 \pm 5.05(\mathrm{a})$ & $15.41 \pm 41.28(\mathrm{ac})$ & 242 \\
\hline 2005 & $2.56 \pm 3.12(\mathrm{~b})$ & $6.02 \pm 16.75(\mathrm{~b})$ & 162 \\
\hline 2006 & $3.17 \pm 3.56(\mathrm{bc})$ & $7.52 \pm 22.5(\mathrm{~b})$ & 461 \\
\hline 2007 & $3.38 \pm 3.98(\mathrm{c})$ & $9.08 \pm 31.68(\mathrm{bc})$ & 463 \\
\hline 2008 & $3.31 \pm 3.31(\mathrm{c})$ & $13.02 \pm 47.6(\mathrm{ac})$ & 458 \\
\hline 2009 & $3.16 \pm 4.79(\mathrm{bc})$ & $14.34 \pm 55.52(\mathrm{ac})$ & 461 \\
\hline 2010 & $3.65 \pm 2.42(\mathrm{c})$ & $13.36 \pm 23.62(\mathrm{ac})$ & 447 \\
\hline 2011 & $3.5 \pm 2.96(\mathrm{c})$ & $14.74 \pm 19.97(\mathrm{ac})$ & 454 \\
\hline 2012 & $3.5 \pm 1.48(\mathrm{c})$ & $16.89 \pm 16.18(\mathrm{c})$ & 427 \\
\hline
\end{tabular}


TABle 4. Recovery of $D$. lindenii based on root characteristics. The 2003 data are pre-hurricane. Traits values followed by different letters are significantly different from one another.

\begin{tabular}{|c|c|c|r|}
\hline Years & $\begin{array}{c}\text { Number of living } \\
\text { roots }\end{array}$ & $\begin{array}{c}\text { Mean length of living } \\
\text { roots (cm) }\end{array}$ & $\boldsymbol{n}$ \\
\hline 2003 & $8.67 \pm 3.54(\mathrm{a})$ & $10.19 \pm 4.88(\mathrm{a})$ & 153 \\
\hline 2004 & $3.62 \pm 3.74(\mathrm{~b})$ & $6.74 \pm 5.05(\mathrm{~b})$ & 64 \\
\hline 2005 & $6.51 \pm 3.53(\mathrm{~d})$ & $8.67 \pm 5.22(\mathrm{ac})$ & 58 \\
\hline 2006 & $6.45 \pm 3.14(\mathrm{~d})$ & $11.88 \pm 5.49(\mathrm{~cd})$ & 342 \\
\hline 2007 & $5.74 \pm 2.63(\mathrm{~cd})$ & $12.29 \pm 6.55(\mathrm{~cd})$ & 304 \\
\hline 2008 & $6.29 \pm 2.25(\mathrm{~d})$ & $12.71 \pm 6.63(\mathrm{~d})$ & 274 \\
\hline 2009 & $5.87 \pm 3.79(\mathrm{~cd})$ & $12.19 \pm 8.16(\mathrm{~cd})$ & 301 \\
\hline 2010 & $5.05 \pm 2.46(\mathrm{c})$ & $13.66 \pm 8.76(\mathrm{de})$ & 248 \\
\hline 2011 & $6.21 \pm 2.95(\mathrm{~d})$ & $14.83 \pm 8.98(\mathrm{e})$ & 243 \\
\hline
\end{tabular}

effort, and since 2007 recovery has been slow (Fig. 3). Before Hurricane Ivan, nearly a third of adult $D$. lindenii plants produced flowers (Fig. 4). The immediate impact of the storm was dramatic. No plants produced flowers in the first season after the storm. Recovery has been slow, and the last four census years showed stagnation and perhaps even an indication of decline.

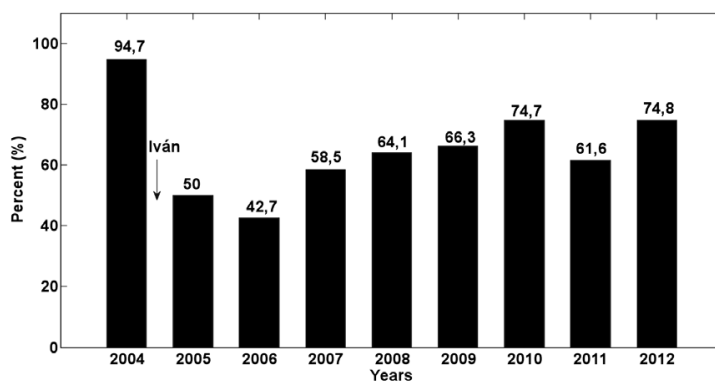

FIgURE 3. Proportion of $B$. cubensis producing flowers annually. The 2004 data were obtained prior to the hurricane.

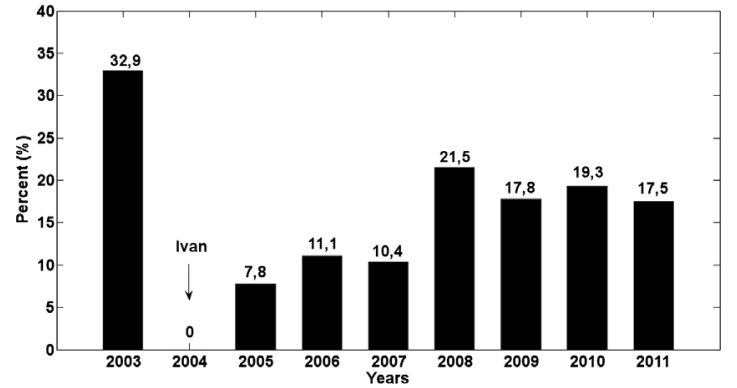

Figure 4. Proportion of D. lindenii producing flowers annually. The 2003 data were obtained prior to the hurricane.
A year after the hurricane there was a slight, non-significant drop in the length of B. cubensis inflorescences (Fig. 5), but subsequently plants of most years (2006, 2008-2012) produced longer inflorescences. In the flowering season after the hurricane, D. lindenii failed to produce inflorescences, but in the following year (2005) plants produced robust inflorescences on a par with pre-hurricane production. Unfortunately, this was not sustained, and in all years since then inflorescence lengths were significantly shorter by $1 / 3$ to $1 / 2$ that of 2003 or 2005 (Fig. 6).

The number of flowers per inflorescence produced by $B$. cubensis was reduced after the hurricane but recovered to pre-hurricane levels by 2012 (Fig. 7). The recovery pattern was similar in $D$. lindenii, although no year was significantly different from any other (except the year after the hurricane when no inflorescences were produced). Inflorescences are usually one- or two- flowered, and there is a non-significant trend for more two-flowered inflorescences over the last three years of censuses (Fig. 8).

Whereas reproductive effort improved for $B$. cubensis, reproductive success did not. Fruit set in the

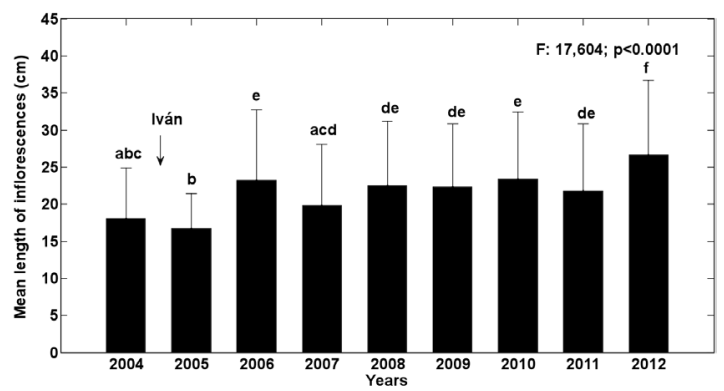

Figure 5. Mean length of the inflorescences in B. cubensis.

The 2004 data were obtained prior to the hurricane.

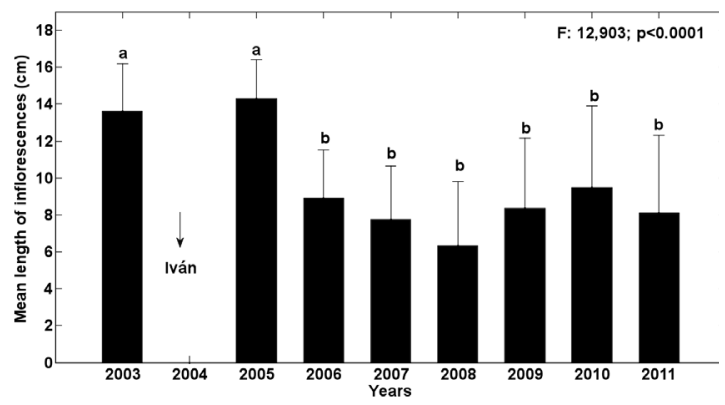

Figure 6. Mean length of the inflorescences in D. lindenii. The 2003 data were obtained prior to the hurricane. 


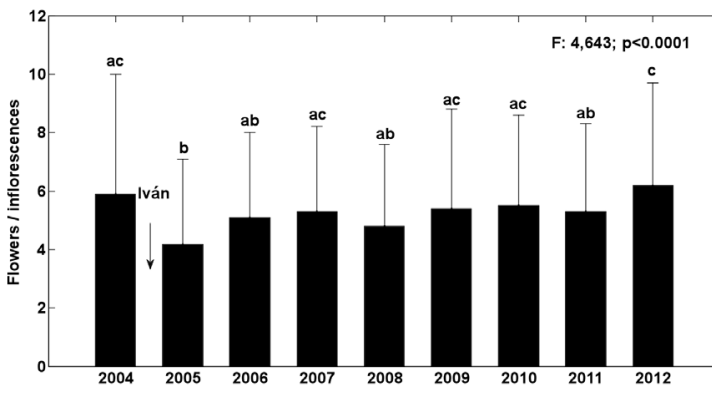

FIGURE 7. Mean number of flowers produced per inflorescence in B. cubensis. The 2003 data were obtained prior to the hurricane.

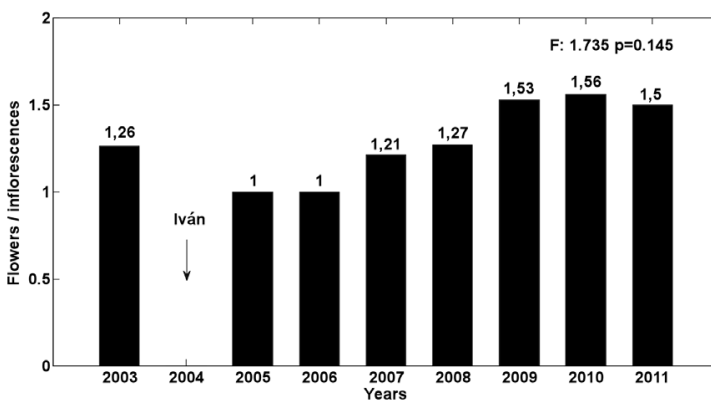

FIGURE 8. Mean number offlowers produced per inflorescence in D. lindenii. The 2003 data were obtained prior to the hurricane.

pre-hurricane year was about $21 \%$, but for all posthurricane years it did not exceed $7 \%$ (Table 5 ). The case of $D$. lindenii is different. Prior to the hurricane there was no fruit set, and occasionally this was repeated through the years. However, sometimes fruit set rose as high as $28 \%$ but was not sustained. The number of fruits produced in the population remained low regardless of the number of flowers produced in the population. Pollinator service for $D$. lindenii in the semideciduous forests of Guanahacabibes is low and erratic (Table 6).

The impact of Hurricane Ivan on demography of B. cubensis and D. lindenii - The population of $B$. cubensis suffered demographically from the hurricane but recovered a year later and was relatively stable even though one plot suffered predation from plant collectors in the last two censuses (Fig. 9). Dendrophylax lindenii also suffered mortality from the passage of Ivan and for a few years showed signs of modest recovery; however, in recent years the number of individuals has declined (Fig. 10).

We assessed population growth of both species
TABLE 5. Fruit set in B. cubensis.

\begin{tabular}{|r|r|r|r|}
\hline Years & \multicolumn{1}{|c|}{ Flowers } & \multicolumn{1}{|c|}{ Fruits } & \multicolumn{1}{|c|}{$\%$} \\
\hline 2004 & 768 & 163 & 21.2 \\
\hline 2005 & 205 & 14 & 6.9 \\
\hline 2006 & 639 & 6 & 0.9 \\
\hline 2007 & 1019 & 10 & 0.9 \\
\hline 2008 & 846 & 11 & 1.3 \\
\hline $\mathbf{2 0 0 9}$ & 1164 & 45 & 3.8 \\
\hline $\mathbf{2 0 1 0}$ & 1667 & 60 & 3.6 \\
\hline $\mathbf{2 0 1 1}$ & 1010 & 14 & 1.4 \\
\hline $\mathbf{2 0 1 2}$ & 1687 & 52 & 3 \\
\hline
\end{tabular}

Table 6. Fruit set in D. lindenii.

\begin{tabular}{|l|r|r|r|}
\hline Years & \multicolumn{1}{|c|}{ Flowers } & Fruits & $\%$ \\
\hline 2003 & 43 & 0 & 0 \\
\hline 2004 & 0 & 0 & 0 \\
\hline 2005 & 4 & 1 & 25 \\
\hline 2006 & 18 & 5 & 28 \\
\hline 2007 & 23 & 0 & 0 \\
\hline 2008 & 46 & 6 & 13 \\
\hline 2009 & 59 & 3 & 5 \\
\hline 2010 & 60 & 3 & 5 \\
\hline 2011 & 43 & 3 & 7 \\
\hline
\end{tabular}

TABLE 7. Yearly and average population growth $(\boldsymbol{\lambda})$ of $B$. cubensis based on matrix analyses.

\begin{tabular}{|c|r|}
\hline Pairs of years & Lambda $(\boldsymbol{\lambda})$ \\
\hline $2006-2007$ & 1.0529 \\
\hline $2007-2008$ & 1.0364 \\
\hline $2008-2009$ & 0.9673 \\
\hline $2009-2010$ & 1.0011 \\
\hline $2010-2011$ & 1.0218 \\
\hline $2011-2012$ & 0.8953 \\
\hline $2006-2012$ & 0.9989 \\
\hline
\end{tabular}

using matrices of plot and transect data since 2006. Broughtonia cubensis was dynamic with four of six year-to-year transitions showing population increases. The most recent decrease (2011-2012) was caused by the loss of 53 individuals that suffered predation (Table 7). To reveal the trajectory of population growth we calculated the mean $\lambda$ from the 2006-2012 censuses for $B$. cubensis and the mean $\lambda$ from the 2005-2011 censuses for D. lindenii. Broughtonia cubensis had a mean $\lambda$ of 1.00 , indicating that over this time period 


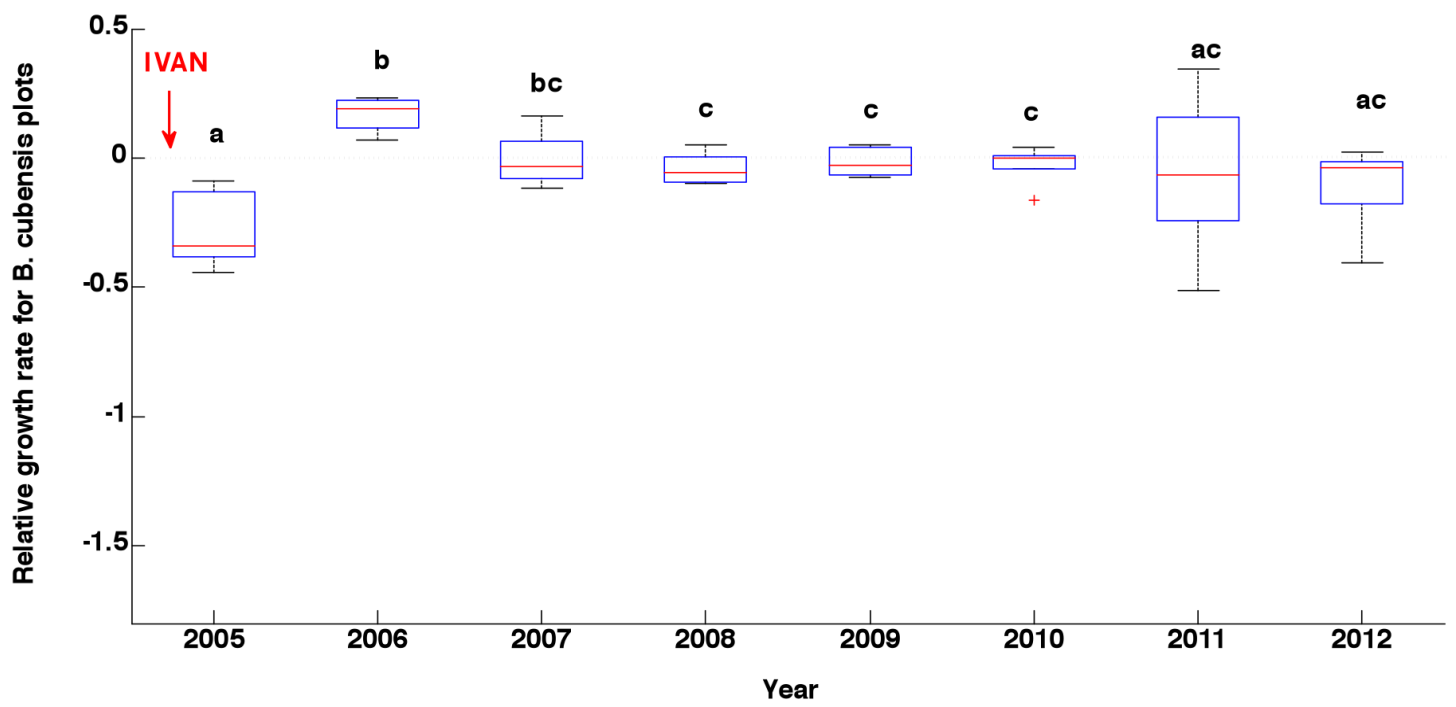

FIGURE 9. Relative population growth rate of B. cubensis. This figure is an extended time analysis of Fig. 6 A-B that appeared in Biotropica 2013.

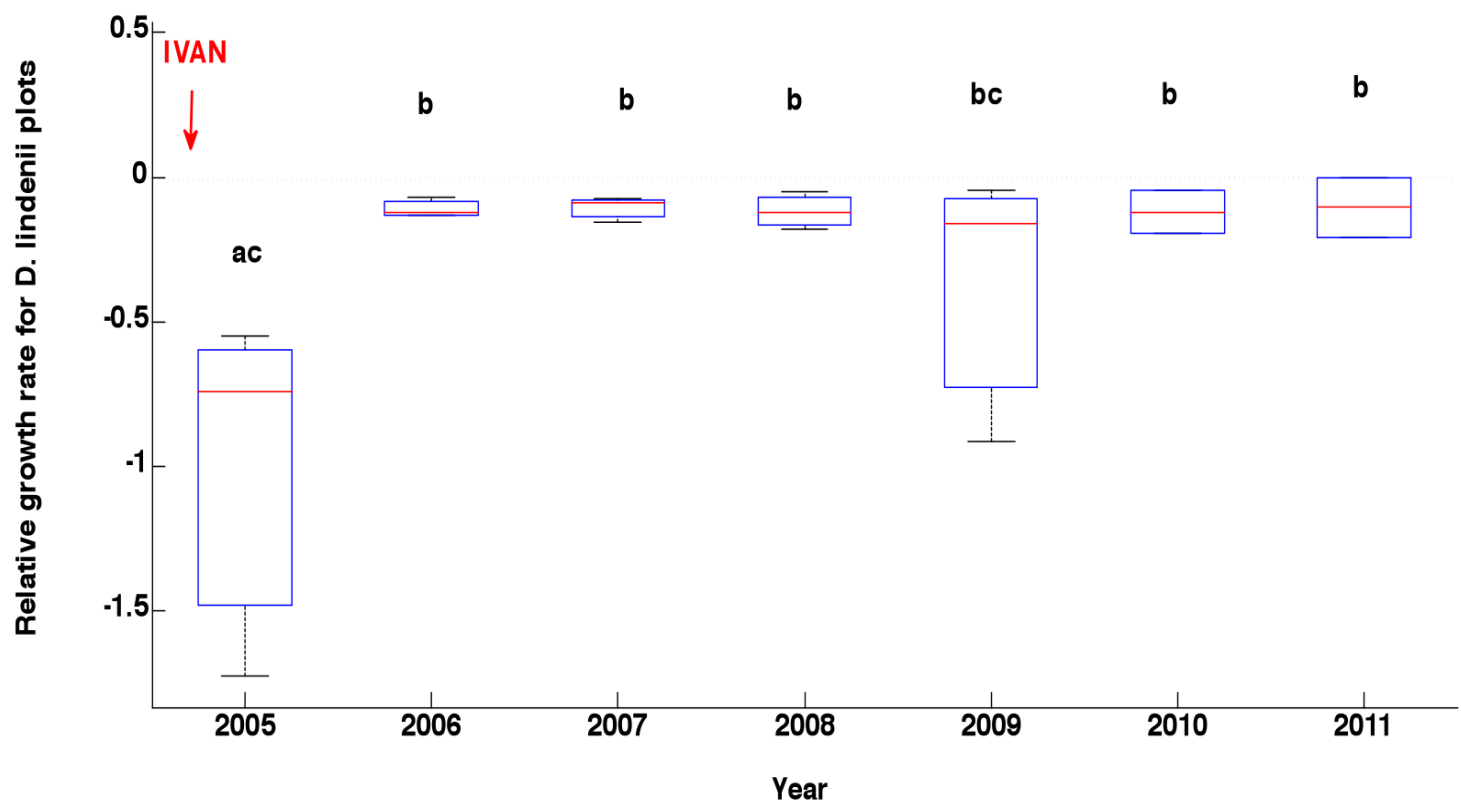

Figure 10. Relative population growth rate of $D$. lindenii. This figure is an extended time analysis of Fig. 6 A-B that appeared in Biotropica 2013.

the population was stable. The average lambda for D. lindenii was 1.05 , indicating a slight increase in population size even though most year-to-year transitions were negative. In 2009, seedlings were all found within $90 \mathrm{~cm}^{2}$ on a single phorophyte causing a high lambda of 1.42 for that year and affecting the overall average.

\section{Discussion}

After the impact of Hurricane Hugo (category 4) in September 18, 1989, on Bisley Watersheds in Puerto Rico, Migenis and Ackerman (1993) observed that the community of epiphytes orchids disappeared. Bayman et al. (2002) reported that Hurricane Georges in Puerto Rico produced significant damage in Big 
TABLE 8. Yearly and average population growth for $D$. lindenii based on matrix analyses.

\begin{tabular}{|c|c|}
\hline Pairs of years & Lambda $(\boldsymbol{\lambda})$ \\
\hline $2006-2007$ & 0.9977 \\
\hline $2007-2008$ & 0.9171 \\
\hline $2008-2009$ & 1.4173 \\
\hline $2009-2010$ & 0.8966 \\
\hline $2010-2011$ & 0.9624 \\
\hline $2006-2011$ & 1.0541 \\
\hline
\end{tabular}

Gulch forest with pronounced negative consequences in the epiphyte community. According to the studies of Tanner et al. (1991), the range of damage of a hurricane on a forest varies considerably from country to country. This study demonstrates that all the phorophyte communities located in the same area did not suffer equally.

Generally the studies carried out in the areas impacted by hurricanes show that trees of high DBH rate are more susceptible to being severely affected by the fracture of trunks and branches (Webb 1989; Gresham et al. 1991). Bellingham and Tanner (1995), in their studies about the consequences of the impact of the Hurricane Gilbert in September of 1988 in Jamaica, did not find height and DBH of trees severely affected. The height of $B$. cubensis phorophytes was not associated with severity of hurricane damage to those trees. On the other hand, trees with larger diameters suffered more. In the semi-deciduous forest habitat of D. lindenii, the tallest phorophytes were more severely affected, and damage class was unrelated to DBH. We conclude that damage severity is both taxon-dependent and habitat-dependent. The same was observed by Walker et al. (1992) after the effects of Hurricane Hugo on a Puerto Rican rain forest.

The height to which individual orchids are on the phorophytes did not play any role on the degree of damage by Hurricane Ivan. All orchids have an equal chance of being affected. Six years after Hurricane Ivan, certain vegetative traits of the two species have not yet fully recovered: average number of leaves per individual for $B$. cubensis and the number of live roots of $D$. lindenii. However, average leaf area of $B$. cubensis and average length of live roots of $D$. lindenii were higher six years after the storm than before it. Apparently, investment in leaf (B. cubensis) and root
(D. lindenii) photosynthetic area has priority over the production of more leaves and roots.

Reproductive effort has yet to fully recover as the percentage of adults producing flowers remained below pre-hurricane levels for both species. The increase of leaf area in B. cubensis apparently reflected positively on the average increase in length of the inflorescence. As for the mean number of flowers per inflorescence, both species showed a full recovery. For both species, most worrisome are the low rates of fruit set, apparently caused by the negative impact of the hurricane on the community of pollinators; however, after Hurricane Hugo in Puerto Rico, pollinator activity was higher than in any of the previous years monitored (Ackerman and Moya 1996).

The growth rate of $D$. lindenii since Hurricane Ivan has been continuously decreasing, whereas the gradual recovery of $B$. cubensis has been affected by predation. The matrix analysis has shown that the $B$. cubensis population is stable, but paradoxically the growth trend of $D$. lindenii is generally upward for the transition that occurred in 2008-2009. However, later the species showed a sharp decrease, indicating little possibility of maintaining a superior lambda or close to 1 that allows an upward curve recovery.

\section{LiTERATURE CITED}

Ackerman, J.D. \& S. Moya. 1996. Hurricane aftermath: resiliency of an orchid-pollinator interaction in Puerto Rico. Caribbean J. Sci. 32: 369-374.

Bayman, P., E.J. González, J.J. Fumero \& R.L. Tremblay. 2002. Are fungi necessary? How fungicides affect growth and survival of the orchid Lepanthes rupestris in the field. J. Ecol. 90: 1002-1008.

Bellingham, P.J. \& E.V.J. Tanner. 1995. Damage and responsiveness of Jamaican montane tree species after disturbance by a hurricane. Ecol. 76: 2562-2580.

Caswell, H. 2001. Matrix population models: construction, analysis, and interpretation, 2nd ed. Sinauer Associates, Inc., Sunderland, Massachusetts.

Harper, J.L. 1977. Population biology of plants. Academic Press, New York.

Herrera, M., G. Alfonso \& R. Herrera. 1987. Las reservas de la biosfera en Cuba. Instituto de Ecología y Sistemática, Academia de Ciencias de Cuba.

Kindlmann, P., J.H. Willems \& D.F. Whigham. 2002. Trends and fluctuations and underlying mechanisms in terrestrial orchid populations. Backhuys, Leiden.

Landsea, C.W., R.A. Pielke, A.M. Mestas-Nuñez \& J.A. 
Knaff. 1999. Atlantic basin hurricanes: indices of climatic changes. Climate Change 42: 89-129.

Lefkovitch, L.P. 1965. The study of population growth in organisms grouped by stages. Biometrics 21: 1-18.

Lodge, D.J. \& W.H. McDowell. 1991. Summary of ecosystem-level effects of Caribbean hurricanes. Biotropica, 23(4), Part A. Special issue: Ecosystem, plant, and animal responses to hurricanes in the Caribbean. (Dec. 1991), pp. 373-378.

Lugo, A.E., M. Applefield, D.J Pool \& R.B. McDonald. 1983. The impact of Hurricane David on the forest of Dominica. Canad. J. Forest Res. 13: 201-211.

Migenis, L.E. \& J.D. Ackerman. 1993. Orchid-phorophyte relationship in a forest watershed in Puerto Rico. J. Trop. Ecol. 9: 231-240.

Morales, J.F. 2000. Orquídeas, cactus y bromelias del bosque seco. INBio. Santo Domingo de Heredia, Costa Rica.

Mújica, E.B., R. Pérez, P.J.L. Trabanco, T. Ramos \& J.L. Bocourt. 2000. Los géneros de orquídeas Cubanas. Editorial Félix Varela, La Habana.

Mújica, E.B. 2007. Ecología de las orquídeas epífitas Broughtonia cubensis (Lindley) Cogniaux, Dendrophylax lindenii (Lindley) Bentham et Rolfe y Encyclia bocourtii Mújica et Pupulin en el Cabo San Antonio, Península de Guanahacabibes, CUBA. Análisis espacio-temporal e implicaciones del impacto de un fenómeno atmosférico severo. Tesis en opción al grado científico de Doctor en Ciencias Ecológicas.

Pielke, Jr., R.A., C. Landsea, M. Mayfield, J. Laver \& R. Pasch. 2005. Hurricanes and global warming. Amer. Meteorological Soc. 86: 1571-1574.

Rodríguez-Robles, J.A., J.D. Ackerman \& E.M. Ackerman. 1990. Host distribution and hurricane damage to an orchid population at Toro Negro Forest, Puerto Rico. Caribbean J. Sci. 26: 163-164.

Salazar, G.A. 1996. Conservation threats. Pp. 6-10 in: Orchids: status survey and conservation action plan (ed. E. Hágsater \& V. Dumont). IUCN. Gland, Switzerland. Sanford, R.L., W.J. Parton, D.S. Ojima \& D.J. Lodge. 1991. Hurricane effects on soil organic matter dynamics and forest production in the Luquillo Experimental Forest, Puerto Rico: results of simulation modeling. Biotropica 23: 343-347.

Schoener, T.W. \& D.A. Spiller. 2006. Nonsynchronous recovery of community characteristics in island spiders after a catastrophic hurricane. Proc. Nat. Acad. Sci. USA 103: 2220-2225.

Spiller, D.A. \& T.W. Schoener. 2007. Alteration of island food-web dynamics following major disturbance by hurricanes. Ecol. 88: 37-41.

Tanner, E.V.J., V. Kapos and J.R. Healey. 1991. Hurricane effects on forest ecosystems in the Caribbean. Biotropica 23(a): 513-521.

Tremblay, R. 2008. Ecological correlates and short-term effects of relocation of a rare epiphytic orchid after Hurricane Georges. Endangered Species Res. 5: 83-90.

Waide, R.B. \& A.E. Lugo 1992. A research perspective on disturbance and recovery of a tropical montane forest. Pp. 173-190 in: Tropical forests in transition (ed. J. G. Goldammer). Birkhauser Verlag, Basel.

Walker, L.R. 1991. Tree damage and recovery from Hurricane Hugo in Luquillo Experimental Forest, Puerto Rico. Biotropica 23: 379-386.

Walker, L., J. Voltzow, J.D. Ackerman, D.S. Fernandez \& N. Fetcher. 1992. Immediate impact of Hurricane Hugo on a Puerto Rican rain forest. Ecol. 73: 691-694.

Webb, S.L. 1989. Contrasting windstorm consequences in two forests, Itasca State Park, Minnesota. Ecol. 70: 1167-1180.

Willig, M.R., C.P. Bloch, N. Brokaw, C. Higgins, J. Thompson \& C.R. Zimmermann. 2011. Cross-scale responses of biodiversity to hurricane and anthropogenic disturbance in a tropical forest. Ecosystems 10: 824838.

You, C. \& W.H. Petty. 1991. Effects of Hurricane Hugo on Manilkara bidentata, a primary tree species in Luquillo Experimental Forest of Puerto Rico. Biotropica 23: 400-406.

Zotz, G., \& G. Schmidt. 2006. Population decline in the epiphytic orchid Aspasia principissa. Biol. Conserv. 129: 82-90. 